\title{
N-Butylpyridoquinoxaline 1,4-dioxide (NBPQD) as a new potent for tumor imaging and therapy
}

\author{
Salem A. Habib ${ }^{1 \#}$, Ismail T. Ibrahim², Mohamed A. Abd-Eldaye ${ }^{3}$, Mamdouh M. El-Sheshtawey ${ }^{4}$, \\ Heba M. Waly ${ }^{1}$

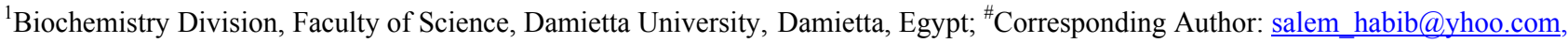 \\ hebawaly88@yahoo.com \\ ${ }^{2}$ Atomic Energy Authority, Cairo, Egypt \\ ${ }^{3}$ Pharmacology Department, Faculty of Veterinary Medicine, Ismailia University, Ismailia, Egypt \\ ${ }^{4}$ Biochemistry Department, Faculty of Pharmacy, Mansoura University, Mansoura, Egypt
}

Received 6 August 2012; revised 10 September 2012; accepted 22 September 2012

\section{ABSTRACT}

The development of new and effective antitumor agents is one of the main goals of medicinal and biochemical research at present. The present study is concerned with the evaluation of the previously synthesized N-Butylpyridoquinoxaline 1,4-dioxide (NBPQD) as an antitumor agent against Ehrlich ascites carcinoma (EAC). The first part of the study (tumor imaging) was to investigate the biodistribution of NBPQD in the organs of EAC-bearing mice using iodine-125 isotope stressing on its distribution in the main organs (stomach, liver, spleen, kidney) in addition to blood and ascetic fluid. The second part was the assessment of the antitumor activity of NBPQD by estimating the tumor volume and the contents of total protein, total lipid, DNA and RNA in liver tissues. In addition, liver function tests and the redox status were assessed. Tumor volume and DNA, RNA, urea and malondialdehyde (MDA) levels and the liver enzymes activity were highly significantly increased $(P<$ 0.001 ) in untreated EAC-bearing mice compared to control. However, total lipid and total protein in liver tissues in addition to serum albumin, glucose, reduced glutathione (GSH) as well as activities of glutathione reductase (GSH-R) and superoxide dismutase (SOD) all were highly significantly decreased in untreated EAC-bearing mice compared to controls. All these decreased parameters were highly significantly restored to their normal levels in NBPQD treated mice compared to the untreated EAC-bearing mice. The survival time of the NBPQD treated mice was

"Declaration of interest: The authors declare that there are no conflicts of interest. longer than that of the untreated ones. It is thus, evident that NBPQD had a remarkable antitumor activity against EAC in Swiss albino mice.

Keywords: Ehrlich Ascites Carcinoma; SOD; MDA; ${ }^{125}$ I-NBPQD; GSH-R; GSH

\section{INTRODUCTION}

Cancer is one of the major causes of death. In cancer cells, reactive oxygen species (ROS) increase the rate of mutagenicity, which leads to DNA damage and chromosomal instability, thereby potentiating cancer progression [1,2]. Also, ROS may promote cell survival and proliferation, thus contributing to cancer development. In addition, the abnormal regulation of ROS has a role in pathological conditions, including inflammation, atherosclerosis, angiogenesis and aging [3].

Oxidative stress is defined as a disturbance in the equilibrium between free radicals (FR), reactive oxygen species (ROS), and endogenous antioxidant defense mechanisms, or more simply, it is a disturbance in oxidantantioxidant states, favoring the oxidant environment [4].

Cells have evolved several antioxidant defenses, including repair and detoxifying enzymes, and small scavenger molecules, such as glutathione. The intracellular ROS-scavenging system includes superoxide dismutases (SOD), glutathione peroxidase (GPx), peroxiredoxins (PRDXs), glutaredoxins, thioredoxins (TRXs), and catalases. In mitochondria, superoxide anion $\left(\mathrm{O}_{2}^{-}\right)$can be dismutated to hydrogen peroxide $\left(\mathrm{H}_{2} \mathrm{O}_{2}\right)$ by two enzymes, namely copper-zinc superoxide dismutase (CuZnSOD) and manganese superoxide dismutase (MnSOD), that are present in the mitochondrial matrix and in the intermembrane space, respectively [5].

SOD mainly functions to provide a defensive action against the potentially damaging reactivities of the super- 
oxide radical generated by all aerobic metabolic reactions. It catalyzes the dismutation of superoxide radical to $\mathrm{H}_{2} \mathrm{O}_{2}$. This protects the cell membrane from damage by ROS. But the decreased SOD levels may lead to increased lipid peroxidation resulting in the cellular rigidity and deformability [6]. This phenomena, i.e. decrease the anti-oxidants and increase in oxidative stress, is more obviously in cancer.

For cancer, the general conventional treatment and standard of care for clinical oncology remains surgery followed by radiation and/or systemic chemotherapy based on the clinical findings [7].

The discovery and development of new and more effective cancer treatment is one of the main goals of medicinal and chemical research in the present days. In recent years the discovery of the antitumor effects of organic compounds particularly quinoxaline derivatives and their possible use in treatment of cancer diseases has received increasing attention. Quinoxaline derivatives have been reported to possess a wide variety of biological activities including antioxidant, anti-inflamematory, antimicrobial, anticancer and antihitaminic activities [8]. The widespread activity of quinoxaline-1,4-di-N-oxide derivatives can be associated with the generation of free radicals. The oxidation of both nitrogens of this heterocyclic system, in order to obtain quinoxaline 1,4-di-Noxide derivatives, increases the number of biological properties enormously [9]. Specific derivatives also show selective cytotoxicity against hypoxic cells present in solid tumors [10].

Many delivery systems able to deliver chemotherapeutic drugs or radioisotopes to the specific tumor site with decreased toxicity to other proliferating tissues, as well as, neighboring tissues were reported [11]. Auger electron emitters are widely used in cellular radiation studies. The most frequently used auger-emitters are iodine125 and iodine-123 [12].

For treatment of cancer, one of the techniques that had been studied is the use of an agent that will be taken up inside the cancer cells. These agents could be incurporated into DNA of dividing cells during the synthesis $\mathrm{S}$ phase. This depends upon the high rate of nucleotide consumption that is prominent in neoplastic cells than in non-neoplastic one [13]. The advantage of auger electron radiation over $\alpha$ radiation is that it does not cause much damage when it is present outside the cell nucleus, such as during transport in blood [14].

Labeling of some quinoxaline derivatives with different radioisotopes like technetium-99 $\mathrm{m}$ or radioiodine was conducted for imaging or therapeutic purposes, respectively [15]. Extensive studies indicated that 3-aminoquinoxaline-2-carbonitrile 1,4-dioxide (AQCD), is more susceptible to reductive activation than tira-pazamine and causes redox-activated DNA damage [16].
Quinoxaline-1,4-dioxide derivatives seem to have interesting anticancer activities especially in solid tumor treatment [17]. Moreover, quinoxaline derivatives may act by the concept of bioreductive alkylation and could cleave the DNA under hypoxic conditions in the presence of xanthine and xanthine oxidase. Recently, radiolabeling of quinoxaline derivatives had been studied and its biodistribution in tumor bearing animals were investigated [16].

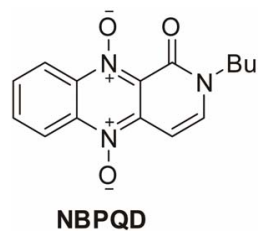

The present work aims are studying the SOD like activity of NBPQD and following up its biodistribution in different organs of the mice using radioactive isotopes in addition to investigating the antitumor effect of this quinoxaline derivative, if any, on Ehrlich ascites carcinoma cells in vitro and in vivo.

\section{MATERIALS AND METHODS}

\subsection{Antitumor Agent}

The quinoxaline derivative, NBPQD, under investigation was synthesized by Dr. M. A. Waly, Chemistry Departement, Faculty of Science, Damietta University, Egypt. 5-Flurouracil (5-FU) was used as a standard antitumor for comparison.

\subsection{Preparation of Labeled NBPQD}

According to the method of Coenen et al. [18] different concentrations of NBPQD was dissolved in dimethylformamide (DMF) and the oxidizing chloramine $\mathrm{T}$ (CAT) was added at different concentrations. About 35 $70 \mathrm{KBq}$ of $\mathrm{NaI}^{125}$ were added and the $\mathrm{pH}$ was adjusted at different values and the mixture was gently heated at different time intervals. The maximum yield of the labeled ${ }^{125} \mathrm{I}-\mathrm{NBPQD}$ was obtained $(94.5 \%)$ at $75 \mu \mathrm{g}$ of substrate (NBPQD) and $200 \mu \mathrm{g}$ of chloramine $\mathrm{T}$ (CAT) as oxidizing agents, at $\mathrm{pH} 7$ after 15 min of starting the reaction. The stability of ${ }^{125}$ I-NBPQD revealed insignificant changes 48 hour after labeling. The iodine attacks the B-position for the enamine part in the pyridine ring of the structure NBPQD.

\subsection{Tumor Cells}

Ehrlich ascites carcinoma cells (EAC) was kindly supplied by the National Cancer Institute, Cairo University, Egypt. The tumor cell line was maintained in Swiss albino mice through serial intraperitoneal transplantation 
of $1 \times 10^{6}$ viable tumor cells suspended in $0.2 \mathrm{ml}$ of saline. The tumor cells were characterized by moderately rapid growth, which kills mice in 16 to 18 days [19].

\subsection{Animals}

All experiments were performed on adult female Swiss albino mice purchased from Theodore Bilharz Research Institute, Giza, Egypt, with an average body weight of 25 to $30 \mathrm{~g}$. Mice were housed in steel mesh cages $(10 \mathrm{mice} /$ cage) and maintained for two weeks acclimatization period on commercial standard diet and tap water. Then, mice were randomly divided into 8 groups, 15 animals each, according to the following scheme:

I-Normal mice saline-treated group (control): Each mouse was intraperitoneally injected with daily $0.2 \mathrm{ml}$ of the physiological saline solution for 10 days.

II-Normal mice DMSO-treated group: Each mouse was intraperitoneally injected with daily $0.2 \mathrm{ml}$ of dimethyl sulphoxide for 10 days.

III-Normal mice NBPQD-treated group: Each mouse was intraperitoneally injected with $16 \mathrm{mg} / \mathrm{kg} /$ day of the NBPQD for 10 days. $16 \mathrm{mg} / \mathrm{Kg}$ /day was chosen since LD50 was estimated in our laboratory to be 160 $\mathrm{mg} / \mathrm{Kg}$ /day (unpublished data).

IV-Normal mice 5-FU-treated group: Each mouse was intraperitoneally injected with $20 \mathrm{mg} / \mathrm{kg} /$ day of $5-$ FU for 10 days as a positive control group [20].

V-EAC-bearing mice saline-treated group: Each mouse was intraperitoneally injected once with $1 \times 10^{6}$ tumor cells. After 24 hours of tumor inoculation, the mouse was intraperitoneally injected with daily $0.2 \mathrm{ml}$ of the physiological saline solution for 10 days.

VI-EAC-bearing mice DMSO-treated group: Each mouse was intraperitoneally injected once with $1 \times 10^{6}$ tumor cells. After 24 hours of tumor inoculation, the mouse was intraperitoneally injected with daily $0.2 \mathrm{ml}$ of DMSO for 10 days.

VII-EAC-bearing mice NBPQD-treated group: Each mouse was intraperitoneally injected once with $1 \times$ $10^{6}$ tumor cells. After 24 hours of tumor inoculation, the mouse was intraperitoneally injected with $0.2 \mathrm{ml}$ solution containing $16 \mathrm{mg}$ NBPQD $/ \mathrm{kg} /$ day for 10 days.

VIII-EAC-bearing mice 5-FU treated group: Each mouse was intraperitoneally injected once with $1 \times 10^{6}$ tumor cells. After 24 hours of tumor inoculation, the mouse was intraperitoneally injected with $0.2 \mathrm{ml}$ solution containing $20 \mathrm{mg} \mathrm{5-FU/kg/day} \mathrm{for} 10$ days. This group served as a positive control group.

At the end of the experiment, 10 mice from each group were sacrifised for blood and tissues collection while the other fives were used to check the mean survival times (MST) and percentage increase in life span (\% ILS) [21].

All procedure described were reviewed and approved by the Animals Ethical Committee of Mansoura Univer- sity.

\subsection{Biochemical Tests}

Total proteins were determined in liver homogenate by the method of Lowery et al. [22]. Nucleic acids were extracted from liver homogenate [23] and DNA content was determined in the extract using the diphenylamine procedure [24] while RNA content was measured by the orcinol procedure [25]. Lipids were extracted from liver tissues by the method of Littelfield et al. [26] while their concentration was determined by the sulfophospho-vanilin method [27]. Total cholesterol, was estimated in serum using a commercial kit (Biocon's, India) according to the instruction of the manufacturer. Glucose in serum was determined enzymatically [28]. Serum alanine transaminase (ALT) and aspartate transaminase (AST) activities were colorimetrically determined [29] and serum albumin was determined by bromocresol green method [30]. Erythrocyte reduced glutathione (GSH) was determined by the method of Beutler et al. [31]. Malondialdehyde (MDA) was determined in liver tissue by the method of Ohkawa et al. [32]. Liver homogenate superoxide dismutase (SOD) activity was assayed spectrophotometrically [33]. Blood hemoglobin ( $\mathrm{Hb}$ ) concentration was colourimetrically determined [34] while total counts of WBCs and platelets were determined using an advanced Bright-Line Haemocytometer (Bosch and Lomb USA) [35]. Protein electrophoresis was carried out using polyacrylamide gel electrophoresis [36].

\subsection{Statistical Analysis}

The results were expressed as mean \pm SD. Differences between groups were assessed by t-test analysis of variance using the Excel software (Microsoft). $\mathrm{P}<0.05$ was considered statistically significant and $\mathrm{P}<0.001$ was considered statistically highly significant for comparison of the results in this study.

\section{RESULTS}

The prepared NBPQD showed SOD-like activity amounting to $6 \%$ inhibition at a concentration $1 \mathrm{mg} / \mathrm{ml}$ and $81 \%$ inhibition at $20 \mathrm{mg} / \mathrm{ml}$ as shown in Figure 1.

As a toxic agent for EAC cells in-vitro, NBPQD showed a similar effect to 5-FU (positive control); the number of viable EAC cells treated with either NBPQD and 5-FU were highly significantly decreased $(\mathrm{P}<0.001)$ compared to those treated with either saline or DMSO Figure 2.

The in-vitro toxicity of ${ }^{125} \mathrm{I}-\mathrm{NBPQD}$ towards EAC cells was observed in (Table 1 and Figure 3). NBPQD showed a high effect on EAC cells. This effect increases with increasing its concentration. Figure 3 (A. untreated 


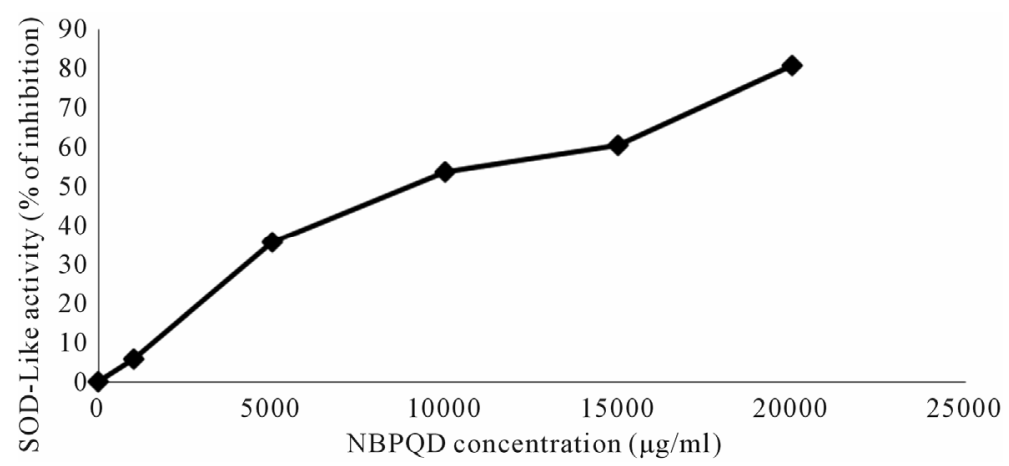

Figure 1. Relation between NBPQD concentration and its SOD-like activity.

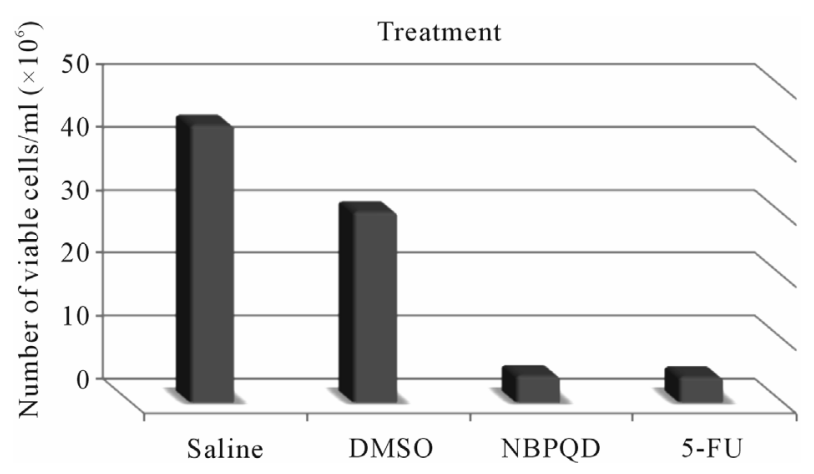

Figure 2. Effect of the different compounds on viability of EAC cells in-vitro.

Table 1. In-vitro-toxicity of ${ }^{125} \mathrm{I}-\mathrm{NBPQD}$ on EAC cells.

\begin{tabular}{cccc}
\hline Dose $(\mathrm{KBq})$ & \% Non viable cells & Dose $(\mathrm{KBq})$ & \% Non viable cells \\
\hline 1 & $3.20 \pm 0.15$ & 8 & $11.3 \pm 1.9^{* \dagger}$ \\
2 & $5.20 \pm 0.35^{*}$ & 16 & $18.5 \pm 3.1^{* \dagger}$ \\
4 & $7.40 \pm 0.40^{* \dagger}$ & 64 & $20.20 \pm 1.2^{*}$ \\
\hline
\end{tabular}

Values represented as $\mathrm{M} \pm \mathrm{SD}$. N. of cases $=6$; ${ }^{*}$ Significantly different from the initial values $(\mathrm{P}<0.05)$; 'Significantly different from the previous values $(\mathrm{P}<0.05)$.

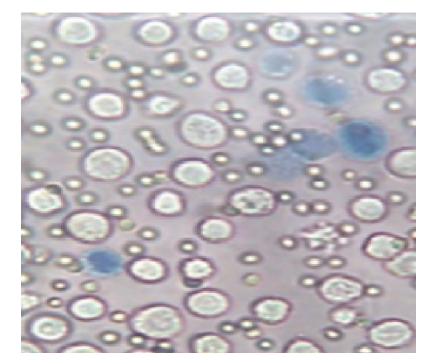

(a)

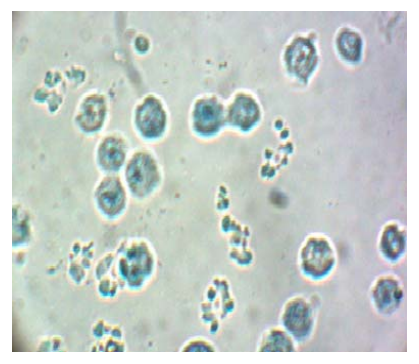

(b)
Figure 3. Viable untreated EAC-cells and non viable EAC cells treated with NBQPD. (a) Viable EAC-cells before treatment; (b) Non viable EAC-cells treated with NBQPD.

viable EAC cells and $B$. non viable EAC cells after treatment with NBPQD).

In normal mice, the uptake of ${ }^{125} \mathrm{I}-\mathrm{NBPQD}$ by blood, lung, intestine, muscle, liver and heart was maximum after $15 \mathrm{~min}$ of injection, after which, the uptake was significantly decreased. However, the maximum uptake of the compound by stomach and thyroid was after one hour and 24 hour of injection respectively (Table 2).

In EAC-bearing mice; maximum uptake of ${ }^{125} \mathrm{I}$ NBPQD was by blood, muscle, heart and intestine 15 min following injection. After $1 \mathrm{~h}, 4 \mathrm{~h}$ and $24 \mathrm{~h}$ of injection the uptake of the compound was significantly decreased. However, ${ }^{125} \mathrm{I}-\mathrm{NBPQD}$ uptake was maxima in bone, liver, lung, stomach, kidney and spleen after $1 \mathrm{~h}$ of injection. Also, the maximum uptake of the compound by thyroid was at $24 \mathrm{~h}$ and by ascetic fluid at $4 \mathrm{~h}$ post injection (Table 3).

Blood $\mathrm{Hb}$ levels in mice of groups $\mathrm{V}$ and VI were significantly decreased while the total count of WBCs and ascetic fluid volume were highly significantly increased compared to those of control mice. On the other hand, the values of $\mathrm{Hb}$ and $\mathrm{WBCs}$ count were not significantly altered in NBPQD- and 5-FU-treated EAC-bearing mice. Moreover, the ascetic fluid disappeared completely in mice of these groups (VII and VIII, Table 4).

Levels of DNA and RNA in liver tissues of tumorbearing mice of groups V and VI were highly signifycantly increased whereas, total lipid and total protein in these mice were highly significantly decreased compared to the levels of controls. These abnormal results were restored to the normal values by treatment of EACbearing mice with either NBPQD or 5-FU (Table 5).

Electrophoretic patterns of liver proteins of normal mice, tumor-bearing mice untreated and tumor-bearing mice treated with NBPQD showed a clear difference between the treated and the untreated tumor-bearing mice protein (Figure 4).

Serum glucose level in mice of groups V and VI was significantly decreased compared to control mice, while, serum levels of urea and cholesterol and the level of MDA in liver tissue were significantly elevated in these mice. Treatment of EAC-bearing mice with either NBPQD or 5-FU restored these parameters to their normal values (Table 6). 
Table 2. Biodistribution of ${ }^{125} \mathrm{I}-\mathrm{NBPQD}$ in normal mice at different time post injection.

\begin{tabular}{|c|c|c|c|c|}
\hline \multirow{2}{*}{ Organs \& Body fluids } & \multicolumn{4}{|c|}{$\%{ }^{125} \mathrm{I}-\mathrm{NBPQD} / \mathrm{g}$ organ/Time post injection } \\
\hline & $15 \mathrm{~min}$ & $1 \mathrm{~h}$ & $4 \mathrm{~h}$ & $24 \mathrm{~h}$ \\
\hline Blood & $12.10 \pm 0.10$ & $10.90 \pm 0.20^{*}$ & $8.70 \pm 0.04^{*}$ & $3.70 \pm 0.30^{*}$ \\
\hline Bone & $2.30 \pm 0.05$ & $2.50 \pm 0.10^{*}$ & $1.90 \pm 0.10^{*}$ & $0.90 \pm 0.10^{*}$ \\
\hline Muscle & $2.10 \pm 0.01$ & $1.70 \pm 0.02^{*}$ & $1.30 \pm 0.10$ & $0.70 \pm 0.02^{*}$ \\
\hline Liver & $5.10 \pm 0.05$ & $4.60 \pm 0.15^{*}$ & $3.20 \pm 0.06^{*}$ & $1.10 \pm 0.02$ \\
\hline Lung & $4.80 \pm 0.10$ & $4.50 \pm 0.12^{*}$ & $2.80 \pm 0.20^{*}$ & $1.10 \pm 0.01^{*}$ \\
\hline Heart & $6.10 \pm 0.80$ & $5.20 \pm 0.30^{*}$ & $3.10 \pm 0.01^{*}$ & $1.20 \pm 0.04^{*}$ \\
\hline Stomach & $8.90 \pm 0.90$ & $11.20 \pm 0.60$ & $9.60 \pm 0.16^{*}$ & $5.70 \pm 0.20^{*}$ \\
\hline Intestine & $6.40 \pm 0.50$ & $6.10 \pm 0.30^{*}$ & $4.50 \pm 0.10^{*}$ & $1.50 \pm 0.03^{*}$ \\
\hline Kidney & $4.70 \pm 0.40$ & $6.20 \pm 0.60^{*}$ & $3.90 \pm 0.30^{*}$ & $1.20 \pm 0.06^{*}$ \\
\hline Spleen & $2.10 \pm 0.30$ & $3.20 \pm 0.10^{*}$ & $2.10 \pm 0.02$ & $1.20 \pm 0.05^{*}$ \\
\hline Thyroid & $4.10 \pm 0.02$ & $6.50 \pm 0.14^{*}$ & $6.70 \pm 0.16^{*}$ & $9.20 \pm 0.20^{*}$ \\
\hline
\end{tabular}

Values represented as $\mathrm{M} \pm \mathrm{SD}$. N. of cases $=6 ;{ }^{*}$ Significantly differ from each previous value $(\mathrm{p}<0.05)$.

Table 3. Biodistribution of ${ }^{125} \mathrm{I}-\mathrm{NBPQD}$ in EAC Bearing Mice at different time post injection.

\begin{tabular}{|c|c|c|c|c|}
\hline \multirow{2}{*}{ Organs \& Body fluids } & \multicolumn{4}{|c|}{$\%{ }^{125} \mathrm{I}-\mathrm{NBPQD} / \mathrm{g}$ organ Time post injection } \\
\hline & $15 \mathrm{~min}$ & $1 \mathrm{~h}$ & $4 \mathrm{~h}$ & $24 \mathrm{~h}$ \\
\hline Blood & $10.70 \pm 0.10$ & $8.10 \pm 0.40^{*}$ & $5.10 \pm 0.10^{*}$ & $3.20 \pm 0.15^{*}$ \\
\hline Bone & $1.70 \pm 0.15$ & $3.30 \pm 0.15^{*}$ & $2.40 \pm 0.15^{*}$ & $1.80 \pm 0.17^{*}$ \\
\hline Muscle & $2.25 \pm 0.09$ & $1.90 \pm 0.02^{*}$ & $1.70 \pm 0.01^{*}$ & $1.20 \pm 0.04^{*}$ \\
\hline Liver & $4.70 \pm 0.25$ & $7.10 \pm 0.20^{*}$ & $4.80 \pm 0.06^{*}$ & $2.50 \pm 0.07^{*}$ \\
\hline Lung & $3.50 \pm 0.10$ & $4.50 \pm 0.04^{*}$ & $3.10 \pm 0.10^{*}$ & $1.30 \pm 0.10^{*}$ \\
\hline Heart & $4.50 \pm 0.30$ & $4.00 \pm 0.40^{*}$ & $2.00 \pm 0.10^{*}$ & $1.40 \pm 0.12^{*}$ \\
\hline Stomach & $8.10 \pm 0.30$ & $13.10 \pm 0.90^{*}$ & $9.10 \pm 0.60^{*}$ & $7.10 \pm 0.50^{*}$ \\
\hline Intestine & $5.10 \pm 0.50$ & $4.50 \pm 0.07^{*}$ & $3.10 \pm 0.10^{*}$ & $1.20 \pm 0.20^{*}$ \\
\hline Kidney & $4.50 \pm 0.40$ & $6.20 \pm 0.10^{*}$ & $4.50 \pm 0.10^{*}$ & $2.20 \pm 0.06^{*}$ \\
\hline Spleen & $1.30 \pm 0.10$ & $2.30 \pm 0.01^{*}$ & $2.30 \pm 0.01^{*}$ & $1.10 \pm 0.0^{*}$ \\
\hline Thyroid & $5.30 \pm 0.02$ & $6.30 \pm 0.04^{*}$ & $8.10 \pm 0.06^{*}$ & $10.20 \pm 0.05$ \\
\hline Ascetic fluid & $3.20 \pm 0.20$ & $6.20 \pm 0.40^{*}$ & $7.20 \pm 0.10^{*}$ & $4.30 \pm 0.05^{*}$ \\
\hline
\end{tabular}

Values represented as $\mathrm{M} \pm \mathrm{SD}$. N. of cases $=6$; ${ }^{*}$ Significantly different from the initial value of each organ $(\mathrm{P}<0.05)$.

Table 4. Total volume of EAC cells, hemoglobin concentration and the total count of $\mathrm{WBC}_{\mathrm{S}}$ in mice of groups I - VIII.

\begin{tabular}{|c|c|c|c|c|}
\hline Group & Parameter & Tumor volumes (ml) & Blood hemoglobin $(\mathrm{g} \%)$ & White blood corpuscle/c.mm \\
\hline & Group I & 0 & $15.04 \pm 2.10$ & $6700 \pm 2714$ \\
\hline & Group II & 0 & $14.16 \pm 1.10^{\mathrm{ns}}$ & $5200 \pm 346^{\mathrm{ns}}$ \\
\hline & Group III & 0 & $15.1 \pm 1.80^{\text {ns }}$ & $8200 \pm 2969^{\text {ns }}$ \\
\hline & Group IV & 0 & $15.26 \pm 1.30^{\mathrm{ns}}$ & $7800 \pm 2089^{\mathrm{ns}}$ \\
\hline & Group V & $15.20 \pm 2.10$ & $12.00 \pm 0.80^{*}$ & $21450 \pm 7230^{*}$ \\
\hline & Group VI & $14.75 \pm 2.81$ & $11.60 \pm 1.42^{*}$ & $23500 \pm 6763^{*}$ \\
\hline & Group VII & 0 & $14.90 \pm 1.33^{\mathrm{ns}, \mathrm{a}}$ & $8875 \pm 1621^{\mathrm{ns}, \mathrm{a}}$ \\
\hline & Group VIII & 0 & $15.75 \pm 4.42^{\mathrm{ns}, \mathrm{a}}$ & $8340 \pm 1828^{\text {ns,a }}$ \\
\hline
\end{tabular}

Values represented as $\mathrm{M} \pm \mathrm{SD}$. N. of cases $=10 ;{ }^{\mathrm{ns}}$ non significant $(\mathrm{p}>0.05)$ when compared to group I; ${ }^{*}$ Significant $(\mathrm{P}<0.05)$ when compared to group I; ${ }^{\mathrm{a}}$ significant $(\mathrm{P}<0.05)$ when groups VII and VIII compared to group V. 
Table 5. Levels of total lipids, RNA, DNA and total proteins in liver tissue homogenate in mice of groups I - VIII.

\begin{tabular}{|c|c|c|c|c|}
\hline Group Parameter & Total lipid mg/g tissue & DNA (mg/g tissue) & RNA (mg/g tissue) & Total protein ( $\mathrm{mg} / \mathrm{gm}$ tissue) \\
\hline Group I & $353.00 \pm 58.00$ & $2.04 \pm 0.65$ & $6.22 \pm 1.10$ & $20.00 \pm 0.20$ \\
\hline Group II & $334.00 \pm 104.10^{\mathrm{ns}}$ & $1.80 \pm 0.33^{\text {ns }}$ & $6.20 \pm 2.10^{\mathrm{ns}}$ & $19.45 \pm 0.50^{\mathrm{ns}}$ \\
\hline Group III & $183.33 \pm 12.0^{0^{*}}$ & $1.9 \pm 0.33^{\mathrm{ns}}$ & $8.00 \pm 1.00^{\mathrm{ns}}$ & $18.00 \pm 1.44^{\mathrm{ns}}$ \\
\hline Group IV & $192.32 \pm 56.10^{*}$ & $1.80 \pm 0.33^{\mathrm{ns}}$ & $8.00 \pm 1.00^{\mathrm{ns}}$ & $20.00 \pm 0.30^{\mathrm{ns}}$ \\
\hline Group V & $48.00 \pm 15.00^{*}$ & $3.0 \pm 0.26^{*}$ & $9.00 \pm 1.00^{*}$ & $14.00 \pm 1.30^{* *}$ \\
\hline Group VI & $50.00 \pm 21.00^{*}$ & $2.85 \pm 0.25^{*}$ & $9.00 \pm 1.00^{*}$ & $16.30 \pm 0.51^{* *}$ \\
\hline Group VII & $179.33 \pm 18.50^{*}, \mathrm{~b}$ & $1.96 \pm 0.35^{\mathrm{ns}, \mathrm{b}}$ & $7.52 \pm 0.31^{\mathrm{ns}, \mathrm{a}}$ & $19.00 \pm 1.00^{\mathrm{ns}, \mathrm{b}}$ \\
\hline Group VIII & $166.41 \pm 45.72^{*}, \mathrm{~b}$ & $1.94 \pm 0.32^{\mathrm{ns}, \mathrm{a}}$ & $7.54 \pm 0.41^{\mathrm{ns}, \mathrm{a}}$ & $19.10 \pm 0.40^{\mathrm{ns}, \mathrm{b}}$ \\
\hline
\end{tabular}

Values represented as $\mathrm{M} \pm \mathrm{SD}$. N. of cases $=10 ;{ }^{\mathrm{ns}}$ non significant $(\mathrm{P}>0.05)$ when compared to group I; ${ }^{*}$ significant $(\mathrm{P}<0.05)$ when compared to group $\mathrm{I}$; ${ }^{* *}$ highly significant $(\mathrm{P}<0.001)$ when compared to group I; bighly significant $(\mathrm{p}<0.001)$ when groups VII and VIII compared to group V.

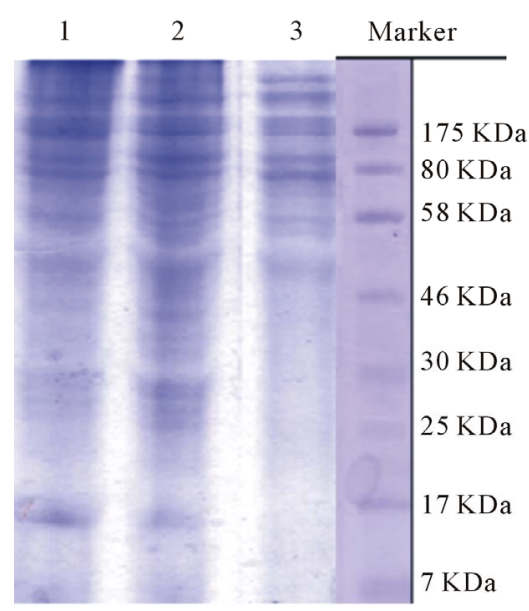

Figure 4. SDS-PAGE for liver proteins of normal mice (lane 2), tumorbearing mice treated with NBPQD (lane 1) and tumor-bearing mice untreated (lane 3) using prestained broad range protein marker (marker).

Erythrocyte GSH concentration and GSH-R activity and liver homogenate SOD activity in tumor-bearing mice treated with saline (group V) or DMSO (group VI) were significantly decreased compared to their values in control mice. In EAC-bearing mice treated with either NBPQD (GVII) or 5-FU (GVIII) no significant changes in these parameters could be observed compared to their corresponding values in control mice (Table 7).

Serum activities of AST and ALT in mice of groups V and VI were significantly increased while serum albumin showed significant decrease compared to the corresponding values of control mice. Treatment with either NBPQD or 5-FU restored these parameters to their normal levels (Table 8).

The mean survival time increased from $15.0 \pm 0.1$ days for tumor-bearing mice saline treated to $35.5 \pm 0.23$ and $39.5 \pm 0.16$ days for tumor-bearing mice NBPQD- treated and 5-FU-treated respectively with increases in life span percent (ILS\%) of $136.66 \%$ and $163.33 \%$ respectively (Table 9).

\section{DISCUSSION}

Specific targeting of tumor cells to achieve higher drug levels in tumor tissue and to overcome the side effects is the major goal in cancer therapy [37]. The present study was conducted using a newly synthesized quinoxaline derivative NBPQD labeled with iodine 125 to be used as a vehicle to deliver radioisotope directly to the nucleus. The effect of this quinoxaline derivative was investigated in EAC cells in vitro and in EAC-bearing mice. It was found that the ${ }^{125} \mathrm{I}-\mathrm{NBPQD}$ has a high cytotoxicity against EAC cells in-vitro. The radiotoxicity of ${ }^{125}$ I-NBPQD increased with increasing the concentration of this compound (Table 1). As a planer compound the radiotoxicity of ${ }^{125}$ I-NBPQD may be due to DNA double strand break that takes place when ${ }^{125} \mathrm{I}-\mathrm{NBPQD}$ is introduced to tumor cells [38].

On the light of these results, in addition to its SODlike activity (Figure $\mathbf{1}$ and Table 1), the antitumor effect of NBPQD in EAC-bearing mice model was investigated and its biodistribution in the different organs after it has been labeled with ${ }^{125}$ I were studied. The biodistribution of ${ }^{125} \mathrm{I}$-NBPQD was performed in normal and tumor bearing mice at different time intervals. In normal mice, the biodistribution of ${ }^{125} \mathrm{I}-\mathrm{NBPQD}$ was rapid in blood, liver, lung, muscles, intestine and heart (Table 2). The rapid decline in ${ }^{125} \mathrm{I}-\mathrm{NBPQD}$ concentration in blood and these organs after 15 min of injection may be attributed to the rapid excretion through kidney [39]. In other organs like stomach and kidney the uptake of ${ }^{125}$ I-NBPQD was maximum after $1 \mathrm{~h}$ of injection.

In EAC-bearing mice, blood concentration of ${ }^{125} \mathrm{I}-$ NBPQD was highest after $15 \mathrm{~min}$. and then rapidly declined. This decrease in blood ${ }^{125}$ I-NBPQD level may be 
Table 6. Levels of glucose, urea and total cholestrol in serum and levels of and MDA in liver tissue homogenate in mice of groups (I - VIII).

\begin{tabular}{|c|c|c|c|c|}
\hline Group Parameter & Glucose (mg\%) & Urea $(\mathrm{mg} \%)$ & Cholesterol (mg\%) & MDA $(\mu$ mole $/ g$ tissue $) \times 10^{-6}$ \\
\hline Group I & $154.00 \pm 35.30$ & $28.00 \pm 5.00$ & $63.00 \pm 9.52$ & $2.00 \pm 1.00$ \\
\hline Group II & $74.24 \pm 18.40^{*}$ & $28.00 \pm 10.30^{\mathrm{ns}}$ & $60.00 \pm 6.00^{\mathrm{ns}}$ & $2.00 \pm 0.41^{\mathrm{ns}}$ \\
\hline Group III & $149.00 \pm 39.00^{\mathrm{ns}}$ & $27.15 \pm 2.00^{\mathrm{ns}}$ & $56.13 \pm 4.00^{\mathrm{ns}}$ & $2.00 \pm 1.00^{\mathrm{ns}}$ \\
\hline Group IV & $159.10 \pm 55.10^{\mathrm{ns}}$ & $23.53 \pm 4.00^{\mathrm{ns}}$ & $58.33 \pm 12.32^{\mathrm{ns}}$ & $2.00 \pm 0.20^{\mathrm{ns}}$ \\
\hline Group V & $88.00 \pm 32.20^{*}$ & $40.03 \pm 5.54^{*}$ & $107.00 \pm 12.00^{*}$ & $3.00 \pm 0.34^{*}$ \\
\hline Group VI & $81.00 \pm 37.00^{*}$ & $32.00 \pm 1.00^{*}$ & $102.00 \pm 1.80^{* *}$ & $3.42 \pm 0.20^{*}$ \\
\hline Group VII & $146.00 \pm 20.30^{\mathrm{ns}, \mathrm{a}}$ & $28.00 \pm 5.01^{\mathrm{ns}, \mathrm{a}}$ & $61.30 \pm 10.80^{\mathrm{ns}, \mathrm{b}}$ & $2.00 \pm 0.30^{\mathrm{ns}, \mathrm{a}}$ \\
\hline Group VIII & $150.00 \pm 19.30^{\mathrm{ns}, \mathrm{a}}$ & $28.00 \pm 4.00^{\mathrm{ns}, \mathrm{a}}$ & $64.00 \pm 7.12^{\mathrm{ns,b}}$ & $2.00 \pm 0.20^{\mathrm{ns}, \mathrm{a}}$ \\
\hline
\end{tabular}

Values represented as $\mathrm{M} \pm \mathrm{SD}$. N. of cases $=10 ;{ }^{n}$ non significant $(\mathrm{P}>0.05)$ when compared to group I; ${ }^{*}$ Significant $(\mathrm{P}<0.05)$ when compared to group $\mathrm{I}$; ${ }^{* *}$ Highly significant $(\mathrm{p}<0.001)$ when compared to group I; ${ }^{a}$ significant $(\mathrm{P}<0.05)$ and bhighly significant $(\mathrm{P}<0.001)$ when groups VI and VIII compared to group V.

Table 7. Erythrocytes GSH content and GSH-R activity in $\mathrm{RBC}_{\mathrm{S}}$ and SOD activity(\% of inhibition) in homogenate of liver tissue in groups (I - VIII).

\begin{tabular}{|c|c|c|c|}
\hline Group Parameter & $\mathrm{GSH}(\mathrm{mmole} / \mathrm{ml}$ cells $)$ & GSH-R (U/L) & SOD ( $\%$ of inhibition) \\
\hline Group I & $1.51 \pm 0.30$ & $61.00 \pm 5.44$ & $33.00 \pm 11.00$ \\
\hline Group II & $1.31 \pm 0.23^{\mathrm{ns}}$ & $73.00 \pm 9.40^{\mathrm{ns}}$ & $32.00 \pm 5.00^{\mathrm{ns}}$ \\
\hline Group III & $2.00 \pm 0.10^{\mathrm{ns}}$ & $60.42 \pm 5.00^{\mathrm{ns}}$ & $22.40 \pm 2.20^{\mathrm{ns}}$ \\
\hline Group IV & $1.80 \pm 0.30^{\mathrm{ns}}$ & $57.00 \pm 11.10^{\text {ns }}$ & $29.00 \pm 5.00^{\mathrm{ns}}$ \\
\hline Group V & $0.75 \pm 0.10^{*}$ & $43.20 \pm 11.40^{*}$ & $14.04 \pm 4.20^{*}$ \\
\hline Group VI & $0.47 \pm 0.06^{*}$ & $37.00 \pm 7.24^{*}$ & $10.30 \pm 2.00^{*}$ \\
\hline Group VII & $1.00 \pm 0.13^{\mathrm{ns}, \mathrm{a}}$ & $68.00 \pm 18.00^{\mathrm{ns,a}}$ & $24.20 \pm 2.52^{\mathrm{ns}, \mathrm{a}}$ \\
\hline Group VIII & $1.00 \pm 0.10^{\mathrm{ns}, \mathrm{a}}$ & $65.22 \pm 10.33^{\mathrm{ns}, \mathrm{a}}$ & $26.00 \pm 4.52^{\mathrm{ns}, \mathrm{a}}$ \\
\hline
\end{tabular}

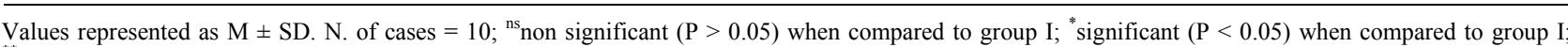
${ }^{* *}$ highly significant $(\mathrm{P}<0.001)$ when compared to group I; ${ }^{a}$ significant $(\mathrm{P}<0.05)$ when groups VII and VIII compared to group V.

Table 8. Serum activities of AST and ALT and serum level of albumin in mice of groups (I - VIII).

\begin{tabular}{|c|c|c|c|}
\hline Group Parameter & AST (unit/ml) & ALT (unit/ml) & Albumin $(\mathrm{gm} \%)$ \\
\hline Group I & $142.50 \pm 12.00$ & $30.33 \pm 11.34$ & $3.00 \pm 0.11$ \\
\hline Group II & $143.30 \pm 12.00^{\mathrm{ns}}$ & $31.30 \pm 9.40^{\mathrm{ns}}$ & $3.00 \pm 1.00^{\mathrm{ns}}$ \\
\hline Group III & $144.30 \pm 30.51^{\mathrm{ns}}$ & $33.00 \pm 12.40^{\mathrm{ns}}$ & $3.00 \pm 0.20^{\mathrm{ns}}$ \\
\hline Group IV & $143.00 \pm 13.00^{\mathrm{ns}}$ & $32.00 \pm 10.00^{\mathrm{ns}}$ & $3.00 \pm 0.30^{\mathrm{ns}}$ \\
\hline Group V & $196.00 \pm 11.32^{*}$ & $57.00 \pm 10.53^{*}$ & $2.47 \pm 0.11^{*}$ \\
\hline Group VI & $191.50 \pm 28.00^{*}$ & $54.00 \pm 9.30^{*}$ & $2.44 \pm 0.20^{*}$ \\
\hline Group VII & $147.00 \pm 8.33^{\mathrm{ns,a}}$ & $33.30 \pm 11.00^{\mathrm{ns}, \mathrm{a}}$ & $3.00 \pm 0.14^{\mathrm{ns}, \mathrm{a}}$ \\
\hline Group VIII & $146.00 \pm 12.20^{\mathrm{ns}, \mathrm{a}}$ & $33.00 \pm 11.00^{\mathrm{ns}, \mathrm{a}}$ & $3.00 \pm 0.12^{\mathrm{ns}, \mathrm{a}}$ \\
\hline
\end{tabular}

Values represented as $\mathrm{M} \pm \mathrm{SD} . \mathrm{N}$. of cases $=10 ;{ }^{\mathrm{ns}}$ non significant $(\mathrm{P}>0.05)$ when compared to group I; ${ }^{*}$ significant $(\mathrm{P}<0.05)$ when compared to group $\mathrm{I}$; ${ }^{* *}$ highly significant $(\mathrm{P}<0.001)$ when compared to group I; ${ }^{\text {a }}$ significant $(\mathrm{P}<0.05)$ when groups VII and VIII compared to group V. 
Table 9. Mean survival time (MST) and increasing life span\% (ILS) of mice of groups V, VI, VII and VIII.

\begin{tabular}{cccc}
\hline Group & Parameter & $\begin{array}{c}\text { Mean survival } \\
\text { time (MST)/day }\end{array}$ & $\begin{array}{c}\text { Increase life span \% } \\
\text { (ILS) }\end{array}$ \\
\hline Group V & $\mathrm{M} \pm$ S.D & $15.00 \pm 0.10$ & - \\
Group VI & $\mathrm{M} \pm$ S.D & $15.50 \pm 0.17$ & 3.33 \\
Group VII & $\mathrm{M} \pm$ S.D & $35.50 \pm 0.23^{* *}$ & 136.66 \\
Group VIII & $\mathrm{M} \pm$ S.D & $39.50 \pm 0.16^{* *}$ & 163.33 \\
\hline
\end{tabular}

${ }^{* *}$ Highly significant $(\mathrm{P}<0.001)$ when groups VII and VIII compared to group V.

attributed to the absorption of the compound by the other organs [13]. However, the majority of other organs showed decline in ${ }^{125}$ I-NBPQD level after $1 \mathrm{hr}$ of injecttion, but in ascetic fluid, ${ }^{125} \mathrm{I}-\mathrm{NBPQD}$ concentration was still at its maximum after $4 \mathrm{hr}$ of injection (Table 3). This long incubation time of ${ }^{125}$ I-NBPQD in ascetic fluid compared to other organs gives more chance for the contact between the compound and the tumor cells and leads to more effect against the tumor.

In cancer chemotherapy the major problems are of myelo suppression and anemia. The anemia encountered in tumor bearing mice is mainly due to the reduction in RBC or hemoglobin percentage and this may occur either due to iron deficiency or due to hemolytic or myelopathic conditions [40]. Treatment of EAC-bearing mice with NBPQD brought back the hemoglobin level and RBCs count near to their normal values (Table 4). This indicates that NBPQD posses a protective action for the heamopoietic system, due to its SOD-like activity which scavenges the free radicals [19].

In tumor-bearing mice the alterations in the activities of many serum hepatic enzyme and protein concentrations are expected due to tumor infiltration to the liver. Also, the increase in RNA and DNA levels in EACbearing mice may be attributed to the high proliferation of the tumor cell (Table 5). Since high proliferation of tumor cells needs high energy, this energy source comes from lipids, proteins and glucose, where their concentration were decreased in the untreated EAC-bearing mice (Tables 5 and 6). In contrast, the metabolites of these components, urea, cholesterol and free radicals like peroxides and MDA were increased (Table 5). After treatment of the tumor-bearing mice with NBPQD, the liver DNA and RNA contents were significantly decreased and therefore the consumption of the energy source components decreased. This decrease in DNA and RNA contents of liver tissue and the increase in total lipids, total protein and glucose in addition to the complete disappearance of tumor ascetic fluid that observed in tumorbearing mice treated with NBPQD support the observations that NBPQD has a marked beneficial effect in this tumor model. This beneficial effect depends on: 1) NBPQD may act by the concept of bioreductive alkylation and could cleave the DNA under hypoxic conditions in the presence of xanthine and xanthine oxidase [16]; or 2) may be due to the double strand break that takes place when NBPQD, as a planer compound, introduced to DNA of tumor cells [38]; or 3) NBPQD produces oxygen radicals that can attack the tumor cells, where, the tumor cells face a reduction in the antioxidants system [16]; or 4) the three possible mechanisms may cooperate to produce this effect.

The levels of lipids and proteins in liver and albumin and glucose in serum of tumor-bearing mice treated with NBPQD were maintained at their normal values compared to those of the untreated tumor-bearing mice. These results are in consistent with previous reports using other antitumor agents [41]. In addition, the electrophoretic analysis of liver protein showed the similarity in protein patterns of normal mice and the tumor bearing mice treated with NBPQD which were both different from the protein patterns of the untreated tumor bearing mice (Figure 4).

On the other hand, the free radical scavenging, SOD present in all oxygen metabolizing cells and their function is to provide a defense against the potentially damaging reactivity's of superoxide and hydrogen peroxide radicals, was inhibited in EAC-bearing mice and associated with the increase in lipid peroxidation [19].

In the present study the treatment of EAC-bearing mice with NBPQD increased the activity of SOD in a dose dependent manner. This may reflect the antioxidant and free radical scavenging property of NBPQD.

Oxygen free radicals are extremely reactive and unstable and react with lipids, proteins, carbohydrates and nucleic acids in the body and generate a cascade producing lipid peroxidation (LPO), a major mechanism of cell membrane destruction and cell damage [42]. Increased lipid peroxidation causes degeneration of tissues, and the lipid peroxides formed in the primary site are transferred through the circulation and provoke damage by propagating the process of lipid peroxidation. MDA is the endproduct of lipid peroxidation and its level is higher in carcinomatous tissue than in non-diseased organs [40].

The results of the present study indicated that the level of MDA in EAC-bearing mice was highly elevated than that of the normal mice. In NBPQD treated EAC-bearing mice, the level of MDA was reduced to the normal value confirming the scavenging effect and SOD-like activity of NBPQD (Figure 1).

This impairment in the cellular redox status may be attributed to the overproduction of reactive oxygen species and the reduction in the anti-oxidants in liver tissues, where, SOD acts to trap superoxide radicals, while GSH can chemically detoxify $\mathrm{H}_{2} \mathrm{O}_{2}$ [43]. 
The observed reduction in GSH levels in tumor-bearing mice in the present study confirm the previously reported results of Farag and Abdel Dayem [43]. This depletion in GSH levels may be attributed either to the increased rate of oxidation of GSH to GSSG by free radical to get rid of $\mathrm{H}_{2} \mathrm{O}_{2}$ or to increase inhibition of $\mathrm{GSH}$ synthesis as a result of the depletion in GSH-R activity [44]. In the present study, the GSH level which was depleted in EAC-bearing mice was increased by treatment of EAC-bearing mice with NBPQD (Table 7).

Hypoproteinemia and hypoalbuminemia may be due to certain cases of massive ascites and also associated with liver disease which confirmed the result of increased ALT and AST activities which may be attributed to hepatic damage as a result of cancer cells invasion [45]. It is not unexpected to find significant elevations in serum activities of AST and ALT and decreased serum albumin level in EAC-bearing mice. Treatment of EACbearing mice with NBPQD caused these parameters to be restored to their normal values (Table 8).

According to Gupta et al. [46] the reliable criteria for judging the value of any anticancer agents tested in experimental animals are the prolongation of life span of the animals. In the present study, the survival time of EAC-bearing mice treated with NBPQD was longer than that of the untreated EAC-bearing mice (Table 9).

\section{CONCLUSION}

On the light of the present results, it is evident that NBPQD had a remarkable antitumor activity against EAC in Swiss albino mice.

\section{ACKNOWLEDGEMENTS}

The authors would like to thank each of Prof. Dr. Ahmed El-waseef for his support and checking this paper and Dr. Mohamed Waly for providing the quinoxaline derivatives.

\section{REFERENCES}

[1] Boulanger, C.A., Wagner, K.U. and Smith, G.H. (2005) Parity-induced mouse mammary epithelial cells are pluripotent, self-renewing and sensitive to TGFb1 expression. Oncogene, 24, 552-556. doi:10.1038/sj.onc. 1208185

[2] Shipitsin, M., Campbell, L.L., Argani, P., Weremowicz, S., et al. (2007) Molecular definition of breast tumor heterogeneity. Cancer Cell, 11, 259-273. doi:10.1016/j.ccr.2007.01.013

[3] Azad, N., Rojanasakul, Y. and Vallyathan, V. (2008) Inflammation and lung cancer: Roles of reactive oxygen/ nitrogen species. Journal of Toxicology and Environmental Health, Part B: Critical Reviews, 11, 1-15. doi:10.1080/10937400701436460

[4] Abdal Dayem, A., Choi, H.Y., Kim, J.H. and Ssang, C.G.
(2010) Role of oxidative stress in stem, cancer, and cancer stem cells. Cancers, 2, 859-884.

doi:10.3390/cancers2020859

[5] Poli, G., Biasi, F. and Chiarpotto, E. (2004) Oxidative stress and cell signaling. Current Medicinal Chemistry, 11, 1163-1182. doi:10.2174/0929867043365323

[6] Naidu, M.S.K., Suryakar, A.N., Swami, S.C., Katkam, R.V. and Kumbar, K.M. (2007) Oxidative stress and antioxidant status in cervical cancer patients. Indian Journal of Clinical Biochemistry, 22, 140-144. doi:10.1007/BF02913333

[7] El-Wahab, S.M.A. and Fouda, F.M. (2009) Histological and histochemical study on the effect of Ehrlich ascites carcinoma on the liver and kidney of mice and the possible protective role of tetrodotoxin. Egyptian Journal of Biology, 11, 13-25.

[8] Ganapathy, S., Ramalingam, P. and Babu Rao, C.H. (2007) Antibacterial, antifungal and antitubercular screening of some novel condensed bridgehead nitrogen heterocycles of quinoxalines. Indian Journal of Heterocyclic Chemistry, 16, 283-286.

[9] Carta, A., Corona, P. and Loriga, M. (2005) Quinoxaline 1,4-dioxide: A versatile scaffold endowed with manifold activities. Current Medicinal Chemistry, 12, 2259-2272. doi:10.2174/0929867054864831

[10] Gali-Muhtasib, H.U., Haddadin, M.J., Rahhal, D.N. and Younes, I.H. (2001) Quinoxaline 1,4-dioxides as anticancer and hypoxia-selective drugs. Oncology Reports, 8, 679- 684.

[11] Xiao, W.H., Dupertuis, Y.M., Mermillod, B., Sun, L.Q., de Tribolet, N. and Buchegger, F. (2000) Unlabeled iododeoxyuridine increases the cytotoxicity and incorporation of iodine-[125] iododeoxyuridine in two human glioblastoma cell lines. Nuclear Medicine Communications, 21, 947-953. doi:10.1097/00006231-200010000-00009

[12] Kassis, A.I., Sastry, K.S.R and Adelestein, S.J. (1987) Kinetics of uptake, retension, and radiotoxicity of 125 IUDR in mmamlian cells: Implications of localised energy depostion by Auger processes. Radiation Research, 109, 78-89. doi: $10.2307 / 3576869$

[13] Dupertuis, Y.M., Buchegger, F. and Pichard, C.B.P. (2003) Deoxyribonucleoside mixture increased the rate of DNA incorporation of 5-[ $\left.{ }^{125} \mathrm{I}\right]$ iodo-2'-deoxyuridine in glioblastoma cells. Cancer Biotherapy \& Radiopharmacuticals, 18, 7-16. doi:10.1089/108497803321269287

[14] Moerlein, S.M., Beer, W. and Stocklin, G. (1988) No Carrier added radio bromination and radioiodoination of aromate rings using in situ, generated peracetic acid. Journal of the Chemical Society, Perkin Transactions, 1, 779-786. doi:10.1039/p19880000779

[15] Brown, J.M. and Koong, A.J. (1999) Therapeutic advantage of hypoxic cells in tumors: A theoritacal study. Journal of the National Cancer Institute, 83, 178-185. doi:10.1093/jnci/83.3.178

[16] Ibrahim, I.T. and Wally, M.A. (2009) Synthesis, labeling and biodistribution of ${ }^{99 \mathrm{~m}} \mathrm{Tc}$-3-amino-2-quinoxalin-carbonitrile 1,4-dioxide in tumor bearing mice. Journal of Radioanalytical and Nuclear Chemistry, 285, 169-175. doi:10.1007/s10967-009-0039-1 
[17] Zarranz, B., Jaso, A., Aldana, I. and Monge, A.B. (2004) Synthesis and anticancer activity evaluation of new 2-alkylcarbonyl and 2-benzoyl-3-trifluoromethyl-quinoxaline 1,4-di-N-oxide derivatives. Medicinal Chemistry, 12, 3711-3721. doi:10.1016/j.bmc.2004.04.013

[18] Coenen, S.M., Moerlein and Stocklin G. (1983) No-carreir-added radiohalogenation methods with heavy halogens. Biochimica Acta, 34, 47-68.

[19] Zahran, R.F. (2009) Biochemical studies on the inhibitory effects of some plant extracts on the growth of Ehrlish ascites carcinoma on mice. M.D. Thesis, Damitta University, Damitta.

[20] Jaganathan, S.K., Mondhe, D., Wani, Z.A., Pal, H.C. and Mandal, M. (2010) Effect of honey and eugenol on herlich ascites and solid carcinoma. Journal of Biomedicine and Biotechnology, 989163.

[21] Gupta, M., Mazumder, U.K., Rath, N. and Mukhopadhyay, D.K. (2000) Antitumor activity of methanolic extract of Cassia fistula L. seed against Ehrlich ascites carcinoma. Journal of Ethnopharmacology, 72, 151-156. doi:10.1016/S0378-8741(00)00227-0

[22] Lowry, O.M., Rosebrough, N.J., Farr, A.L. and Randall, R.J. (1951) Protein measurements with the Folin-phenol reagent. Journal of Biological Chemistry, 193, 265-275.

[23] Schneider, W., Hogeboom, G. and Ross, H. (1950) Intracellular distribution of enzymes and nucleic acid in normal mouse liver and mouse hepatoma. Journal of the $\mathrm{Na}$ tional Cancer Institute, 10, 977-980.

[24] Dische, Z. and Schwartez, K. (1937) Microchemical Methods for determining various pentoses in the presence of one anotherand of hexoses. Mikrochim Acta, 2, 13-19. doi:10.1007/BF01471868

[25] Mejbaum, W. (1939) Estimation of small amount of pentose especially in derives of adenylic acid. $Z$ Physiol Chem, 258, 117-120. doi:10.1515/bchm2.1939.258.2-3.117

[26] Littelfield, L.W., Keller, E.B., Gress, J. and Zamecnick, P.C.J. (1955) Studies on cytoplasmic ribonucleoprotein particles from liver of the rate. Journal of Biological Chemistry, 217, 111-117.

[27] Knight, J.A., Anderson, S. and Rawle, J.M. (1972) Chemical basis of the sulfophospho-vanilin reaction of estimating total lipids. Journal of Clinical Chemistry, 18, 199-203.

[28] Triner, P. (1969) Determination of blood glucose using an oxidase peroxidase system with non-carcinogenic chromogen. Annals of Clinical Biochemistry, 6, 24-30.

[29] Reitman, S. and Frankel, S. (1957) Determination of serum glutamic oxaloacetic and glutamic pyruvic transaminases. American Journal of Clinical Pathology, 28, 5661.

[30] Doumas, B.T., Watson, W.A. and Biggs, H.G. (1971) Albumin standards and the measurement of serum albumin with bromocresol green. Clinica Chimica Acta, 31, 87-93. doi:10.1016/0009-8981(71)90365-2

[31] Beutler, E., Duron, O. and Kelly, B. (1963) Improved method for the determination of blood glutathione. Journal of Laboratory and Clinical Medicine, 61, 882- 890.
[32] Ohkawa, H., Ohish, N. and Yagi, K. (1979) Assay for lipid peroxidase in animal tissues by thiobarbituricacid reaction. Analytical Biochemistry, 95, 351-358. doi:10.1016/0003-2697(79)90738-3

[33] Nishikimi, M., Roa, N.A. and Yogi, K. (1972) The occurrence of superoxide anion in the reaction of reduced phenazine methosulfate and molecular oxygen. Biochemical and Biophysical Research Communications, 46, 849-854. doi:10.1016/S0006-291X(72)80218-3

[34] Drabkin, D.L. and Austin, J.H. (1932) Spectrophotometric constants for common haemoglobin derivatives in human, dog and rabbit blood. Journal of Biological Chemistry, 98, 719-733.

[35] Dacie, S.J.V. and Lewis, S.M. (1984) Practical haematology. 6th Edition, Churchill Livingstone, 22-27.

[36] Leammli, U.K. (1970) Cleavge of structural proteins during the assembly of the head of bacteriophage T4. Nature, 227, 680-685. doi:10.1038/227680a0

[37] Sumanta, K.S., Swatilekha, M., Tapas, K.M., Sudip, K.G. and Panchanan, P. (2011) Hydrophobically modified carboxymethyl chitosan nanoparticles targeted delivery of paclitaxel. Journal of Drug Targeting, 19, 104-113. doi:10.3109/10611861003733987

[38] Unak, T. and Unak, P. (1966) Direct radioiodination of metabolic 8-hydroxy-quinolyl-glucuronide, as a potential anti-cancer drug. Applied Radiation and Isotopes, 47, 645-647. doi:10.1016/0969-8043(95)00333-9

[39] Mannan, R.H., Somayaji, V.V., Lee, J., Mercer, J.R. and Weibe, L.I. (1991) Radiiodinated 1-(5-iodo-5-deoxy- $\beta$-Darabinofuranosyl)-2-nitroimidazole (Iodoazamycin Arabinoside: IAZA): A novel marker of tissue hypoxia. Journal of Nuclear Medicine, 32, 1764.

[40] Subramanian, V. and Gowry, S. (2011) Antitumor activeity and antioxidant role of Brassica oleracea Italica against ehrlich ascites carcinoma in swiss albino mice. Research Journal of Pharmaceutical, Biological and Chemical Sciences, 2, 275-285.

[41] EL-Sayd, I.H. (1998) Effect of some complexes on tumor-bearing animals. Ph.D. Thesis, Mansoura University, Mansoura, 7.

[42] Devaki, M., Nirupama, R. and Yajurvedi, H.N. (2011) Reduced antioxidant status for prolonged period due to repeated stress exposure in rat. Journal of Stress Physiology \& Biochemistry, 7, 13 -147.

[43] Fouda, F.M. (2005) Anti-tumor activity of tetrodotoxin extracted from the Masked Puffer fish Arothron diadematus. Egyptian Journal of Biology, 7, 1-13.

[44] Farag, A.A.M. and Abdel Dayem, S.M. (2001) Biochemical, histological and ultrastructural studies on the protective effect of vitamin A against carcinogenic effect of 7, 12-DMBA on the liver of albino rat. Egyptian Journal of Zoology, 37, 335-368.

[45] Badr, M.O.T., Edrees, N.M.M., Abdallah, A.A.M., Hashem, M.A., El-Deen, N.A.M.N., Neamat-Allah, A.N.F. and Ismail, H.T.H. (2011) Propolis protects against methotrexate induced hepatorenal dysfunctions during treatment of ehrlich carcinoma. Journal of American Science, 7, 313-319. 
[46] Gupta, A., Mazumder, U.K., Kumar, R.S. and Kumar, T.S. (2004) Anti-tumor activity and anti-oxident role of Bauhinia racemosa against Ehrlich ascites carcinoma in
Swiss albino mice. Acta Pharmacologica Sinica, 25, 1070-1076. 